\title{
War permitted under doctrine of necessity not general rule in Islam
}

\author{
JAMSHEED AHMAD SYED*, ARSHID IQBAL DAR** \\ (*Department of Political-Science, University of Kashmir, India)
}

\begin{abstract}
In present situations different concepts about the religion of Islam are floating in the minds of the people. Some hold that the religion of Islam is a religion of wars and terrorism others label Islam with extremism. But in reality, Islam promotes neither terrorism nor encourages extremism. Islam preaches tolerance and moderation. Also Islam forbids killing/bloodshed without valid justification. Therefore this research paper is aimed at providing a clear and true picture picture of "Jihad" which is in consonance with sublime teachings of the Holy Quran and Sunnah of the Prophet Muhammad (PBUH)
\end{abstract}

Key Words:- Religion, Islam, Terrorism, Extremism, Tolerance, Holy Quran, Sunnah

\section{INTRODUCTION}

The misunderstanding that Islam promotes war and sets no limit in means and methods of armed combat is illusive. Islam as a religion of peace abhors aggression and made armed combat a legitimate phenomenon only when it becomes necessary. Even in cases where Islam approves armed combat as a legitimate option and allows Muslims to participate in the hostilities, it has at the same time provided for rules to regulate the conduct of the war. Thus the purpose of this research paper is to explore the Islamic concept of war. The paper also deals with the themes like Muslim concept of international law, difference between Jihad and Qital, Jihad in the meaning of armed combat, Cause of war in Islam. The paper discusses these vital issues comprehensively. It also touché up themes like barbarity before advent of Islam, conduct of war, permission for armed combat. Finally conclusion is given which summarizes the concept of war in Islam.

\section{MUSLIM CONCEPTION OF INTERNATIONAL LAW}

The conduct of war in Islam falls within purview of Muslim international law, known as as-Siyar. Therefore to comprehend the concept and conduct of war in Islam, a brief introduction of law which is concerned with the foreign relation of Islamic state is unavoidable. War and the effects of warfare constitute a significant subject of Siyar literature. ${ }^{1}$ The principles of jus ad bellum (law governing the resort to war) and the jus in bello (content of the law of war) were formulated by Muslims at a time when its contemporaries paid no heed to these rules. ${ }^{2}$ Islamic law therefore, is the first to have formally established a comprehensive rules regarding hostile and peaceful relations between the Muslim and non-Muslim communities. ${ }^{3}$ Siyar (Muslim International Law) has been recognized as an essential part of Islamic law and Islamic jurisprudence. ${ }^{4}$ This law, like other branches of Islamic law, is based primarily on the two fundamental sources-the Quran and the Prophetic traditions. Furthermore like other branches of Islamic law, its rules have been developed in accordance with the conduct or the ,model examplee set by Prophet Muhammad (SAW) in his dealings with the non-Muslims. The term Siyar (plural of Sirah, which literally means conduct or behavior) itself indicate that the conduct of Prophet Muhammad (SAW) in his international dealings and constitutes the basis on which the detailed rules of law were developed. Prophet Muhammad (SAW) fought battles with his enemies; sent legate and emissaries and wrote letters to his contemporary rulers; received delegation; led his followers, and himself participated, in negotiating various treaties and agreements of international import, and dealt with the questions of booty, prisoners of war, and acquisition of enemy property. This entire conduct, coupled with the general principles laid down in the holy Qur"an, provided the foundation for the branch of knowledge called as-Siyar.

\footnotetext{
1 Imam Shaybani, Siyar al Sagir: The Short Book on Muslim International Law translated by Mahmood Ahmad Gazi, Adma Publishers, New Delhi, 2004, p. 5.

2 Muhammad Munir. "Cause of war in Islam: Infidelity or Defence of Faith," Retrieved from http://SSrn.com/abstract=1802003, accessed on January 5, 2015.

3 Shaheen Sadar Ali and Javid Rehman, "The concept of Jihad in Islamic International law," Journal of Conflict and Security Law, 2005. 4 Ibid.
} 
Literally Siyar is the plural of sira which means conduct, practice, comportment, behaviour, way of life, attitude or accepted behaviour and an alternative meaning in its plural form is campaigns. ${ }^{5}$ The words sair, sairura, maser, masira, masaran, tasyar-are used to denote moving (on), setting out, to strike out ,to start, to march, depart; leave. ${ }^{6}$ In Islamic Shariah, Siyar refers to issues regarding the laws of war. Dr Hamidullah define Siyar as "That part of the law and custom of land and treaty obligation which a Muslim de facto or de jure state observe in its dealings with other de facto or de jure state. ${ }^{7}$ Muslim Scholars of the early second century adopted the word Siyar as the name for that branch of Islamic law which specifically deals with the relationship of the Muslim community with other international entities and communities.18 Perhaps the first Muslim jurist who used the term Siyar for Muslim international law in any extant legal compendium was Zayd ibn Ali and by the middle of the second century this term had become an accepted appellation for Muslim international law. ${ }^{8}$ Imam Abu Hanifa was the first Muslim jurist who taught Siyar as a separate legal science. His disciple Imam Shaybani was perhaps the first jurist whose book Kitab Al Siyar Al-Saghir becomes widely known as the first authentic book on as-Siyar. Dr Hamidullah ascribes the origin of Muslim international law to the Prophet"s period of Madina, where Muslim confronted with a war and many problems had to be answered; for instance, should war be declared? And after the war ended it had to be decided whether only adult capable of bearing arms should be killed or should the same fate be meted out to all enemy men, women and children? How is one to treat prisoners of war? In short the host of questions relating to the conduct of war had to be answered. The practice and pronouncements of the Prophet Muhammad (SAW) provided the guidelines for law which came into being and thus was born the concept of Muslim international law. ${ }^{9}$

Regarding the content of Muslim international law, it has an elaborate set of rules concerning the resort to war (jus ad bellum), treaties, the conduct of war (jus in bello), rights of prisoners of war, termination of captivity, and the effects of war. Muslim international law deals with the host of other issues that are essential for conducting the affairs of an Islamic state in the international arena. Further one of significant aspect of asSiyar which guides the Islamic humanitarian law is the concept of Jihad. The term Jihad has been a subject of great debate among Islamic legal scholars, particularly with respect to its meaning, the duty it entails for Muslims and when the use of force is authorized by Islamic law. ${ }^{10}$ Therefore for understanding the concept of jihad in broader sense, it is necessary to differentiate between Jihad and qital.

\section{Why Jihad is different from Qatil}

There are a number of misunderstandings about the concept of "Jihad". The most common misconception regarding term "Jihad" has been created by Muslims themselves by misinterpreting the sacred term. Many Muslim scholars have wrongly declared "Jihad" synonymous with war (qital). There is a fundamental principle of linguistics that no two words of a language are exactly the same. Moreover, "Jihad" and "qital" are two independent terms that are frequently used in the Holy Qur"an. Considering "Jihad" and "qital" identical concepts resulted in confusion and one of the basic terms of Islam was totally distorted which eventually blurred the most sacred duty towards Allah. Therefore it is wrong to consider "Jihad" and "qital" as synonymous term. Few exceptions are there in the holy Qur"ean where these two terms are used interchangeably. However, by and large there is always a fundamental difference between the two terms. Another misunderstanding regarding "Jihad" has been developed with reference to its position in Islamic Shariah. Jihad has been declared as "Farz-e-kifayah" whereas it is "Farz-e-ayn" (an imperative duty incumbent on every Muslim) ${ }^{11} 23$. Actually it is the concept of qital which is "Farz-ekifayah" (a duty which if carried out by some people it absolves all others of their responsibility). Further qital is enforced by Islamic state. Jihad is whatever Muslim does in his practical life within the bounds of Islam, for seeking the pleasure of Allah. If he is fulfilling the duties towards Allah or duties towards his own fellow beings, his kith and kins, it is all "Jihad" (or even (ibadahh). Jihad (strive and struggle) was carried out by the Prophet Muhammad (SAW) for good about 23 years and will continue till the Day of Judgment. As far as qital (war) is concerned it is fought by Muslims to foil the external threat or aggression. In short it is wrong to equate "Jihad" with "qital."Both "Jihad"and"qitaleee are two distinct and independent terms used in the holy Qur"an. "Jihad" is "Farz-e-ayn" which starts at

\footnotetext{
${ }^{5}$ Muhammad, Munir, "Islamic International law (Siyar): An Introduction," Hamdard Islamicus, Vol. XXXX, No.4, October-December 2012, pp.37-60

${ }^{7}$ Muhammad Hamidullah, The Muslim Conduct of State, Sh. Muhammad Ashraf Sons, Lahore, 1973, p. 11.

8 Imam Shaybani, Siyar al Sagir: The Short Book on Muslim International Law translated by Mahmood Ahmad Gazi, Adma Publishers, New Delhi, 2004, p. 7.

9 Muhammad, Hamidullah. The Emergence of Islam, Adam Publishers and Distributors New Delhi, 2010, p.136

10 Abdulrashid Lawan Haruna, "War and Islamic Humanitarian Law: Appraising Warfare and Distinction as a Principle in Hostilities," International Journal of Humanities and Social Science Vol. 4, No. 5(1); 2014.

11 Muhammad Yusuf Islahi, Everyday Fiqh, Islamic Publications Lahore, 1997, p.5.
}

DOI: 10.9790/0837-2206134954 www.iosrjournals.org


individual level and culminates at collective level whereas qital is Farz-e-kifayah. In short "Jihad" is not necessarily qital but qital is certainly the climax of "Jihad."It can be said that, not all war is jihad and not all jihad is war but it has contextual meaning.

\section{Barbarity before the Advent of the Prophet}

To understand the conduct and concept of war in Islam one should know the barbarity that the world of Pre Islamic era used to carry out during the armed combat. The mistreatment of prisoners of war and suffering endured by non-combatants are seemingly unavoidable by-product of armed combat. ${ }^{12}$ The Arabs of Jahilliyyah period used to kill the prisoners of war as well as their women and children and the later used to be burnt in fire. ${ }^{13}$ It is reported that children would be used for target practice with arrows. ${ }^{14}$ Arabs in Jahiliyyah period used to swear that should they overthrow the enemy they would use their skulls for drinking wine. Sulafah-a pagan women from Makkah,whose two sons were killed by Asim b. Thabit in the battle of Uhud-had sworn that she would use Asim "s skull for drinking wine. ${ }^{15}$ They used to tear apart the fetus of pregnant women and used to be proud of it during pre Islamic period. In ancient Greece, treatment with captives constituted a vicious cycle in which the defenders of city would resolutely resist the siege for fear of massacre, mass rape, and enslavement. ${ }^{16}$ For the Romans war was essentially unconstrained and prisoners were routinely slaughtered, enslaved. In the Far East, the Shang rulers of China (1523-1121 B.C.) sacrificed prisoners by decapitation. ${ }^{17}$ Even the Bible, has many examples of warfare being waged without any mercy. When Joshua led the Israelities into Promised Land and promptly laid siege to Jericho they destroyed with the sword every living thing in it-men and women, young and old, cattle, sheep and donkeys. ${ }^{18}$ Prior to the advent of Islam all forms of barbarism and savagery were perpetrated in the warfare. Islam recognized, the rights of those engaged in war.

\section{Jihad in the sense of armed combat}

The perception of Islam on Jihad has been misconstrued by non-Muslims such that whenever the word Jihad is mentioned they understand it to be a holy war against non-Muslims. But the term "holy war" is actually Europeanlinvention and derives from the study of war in its European context. ${ }^{19}$ Jihad cannot be equated semantically with holy war, for its meaning is much broader, includes many activities unrelated to armed combat, and is determined in part by legal criteria that parallel modern just-war thinking in the West. In Arabic, the translation of, "holy war" is not jihad but harb muqaddas, the term which never appears in the holy Quran". The Arabic term jihad has been misused due to misconception, manipulation or distortion of its true meaning. Linguistically, the term Jihad is derived from the Arabic word ,Jahd', which means fatigue, or from the Arabic word ,Juhd', which means effort. Thus, the term Jihad literally means to strive, or to exert one ${ }^{\text {ee }}$ efforts, or to earnestly work towards a desired goal or to prevent an undesired one. In other words, it is an effort (which makes one feel fatigued) that aims at bringing about benefit or preventing harm. 7In the holy Qurean the term "Jihad"eee is basically used for an all-out struggle for a certain cause. The term Jihad is used for right as well as wrong in the holy Qurean. In Sura Ankabut it is said: ,,,those who strive hard (Jahadu) in our (cause) we will certainly guide them to our paths". ${ }^{20}$ In the same sura this very word is used for polytheist parents who used to force their Muslim children "es to assigns partners with Allah: Allah say in the Qurean if they strive to make you join with me (in worship) anything (as a partner) of which you have no knowledge, then obey them not. ${ }^{21}$ Moreover Jihad is multi-dimensional term, referring to struggles of varying levels and circumstances. John Esposito, one of the United Statese foremost authorities and interpreters of Islam, describing it initially as the

12 Bertosa Brain, "The Treatment of Prisoners of War and Non Combatants in the Quran," Canadian Military Journal Spring 2007.

13 Munir, Muhammad, "The Prophet (PBUH) ${ }^{\text {ee }}$ S Merciful Reforms in the conduct of war, The Prohibited Acts," Insights: Mercy for the World, Vol. 2.No.2-3,Winter 2009-Spring 2010, pp. 221260.

14 Shibli Numani and Syed Suleman Nadawi mention the story of the children of Qays who lift their children to Banu Dhabyan and all of them were killed by the later in target practice in front of a large number of people. See Numani and Nadawi, Sirat al Nabi, p. 353.

15 Muhammad Munir, "The Prophet (PBUH) ${ }^{\text {ee }}$ S Merciful Reforms in the conduct of war, The Prophibited Acts,” Insights: Mercy for the World, Vol. 2.No.2-3, Winter 2009, Spring 2010, pp. 221-260.

16 Antony Kalashnikov, "Treatment of Captives in Ancient Greek Warfare: A Vicious Cycle", Vexillum, the Undergraduate Journal Of Classical And Medieval Studies,(2013).

17 John A. Lynn, Battle, A History of Combat and Culture from Ancient Greece to Modern America, West view Press, Boulder, 2003, p.35.

18 Dr Joel Hayward, "Quranic concept of the Ethics of warfare: Challenging the Claims of Islamic Aggressiveness," Occasional Papers. 2, 2011.

19 Reuven Firestone, Jihad: The Origin of Holy War in Islam, New York, Oxford University Press, 1999.

20 Qur"ean, Sura ul Ankabut: verse 69.

21 Quran,Sura ul Ankabut: verse 8. 
struggle pertaining to the difficulty and complexity of living a good life: struggling against the evil in oneself in order to be virtuous and moral. He further adds, that the term jihad can also mean fighting injustice and oppression, spreading and defending Islam, and creating a just society through preaching, teaching and, if necessary, armed struggle. ${ }^{22}$ Therefore term Jihad is comprehensive which is composed of several elements, only one of which involves the use of force or military means under the doctrine of necessity.

\section{Cause of war in Islam}

The Islamic state is obliged to refrain from engaging in armed combat prompted by differences in religious belief or for exploitation of other people's resources...armed combat in Islam is ...permitted to defend the faith, life, Progeny, Property, the territorial integrity of the Islamic state; to defend the oppressed and persecuted, to protect the honour, dignity and freedom of man, and to preserve peace in the world. The following verses of the holy Quran reveals the Islamic perception of motive for armed combat.

And had Allah not checked one set of people by means of another, the Earth would indeed be full of corruption.( Qurean 2:251)

To those against whom war is made, permission is given (to fight), because they are wronged, and verily, God is Most Powerful for their aid (they are) those who have been expelled from their homes in defiance of right, (for no cause) except that they say, "our Lord is God.( Qurean 22:39, 40)And had it not been that Allah dislodges one people through another, the monasteries and churches, the synagogues and the mosques, in which His praise is abundantly celebrated would be utterly destroyed.( Qur"ean22:40) And why should ye not Fight in the cause of God And of those who, being weak, are ill-treated (and oppressed)?-Men, women, and children, whose cry is: "Our Lord Rescue us from this town, whose people are oppressor. ( Quran 4:75)

Humanity has experienced wars and disasters of its own making since the beginning of human society, which are rooted in a vengeful human imperative. Since then, war has developed as social phenomenon and has accompanied humanity on its sojourn through history. ${ }^{23}$ War is the worst thing known to mankind throughout his long history. It brings about the killing and maiming of human beings, the loss of their powers and their defacement causes the destruction of civilizations, stirs up hatred and resentments amongst people, and passes psychological problems on to future generations. For these reasons, armed combat must be avoided at all costs and if it becomes necessary - because the enemy has forced the situation - it is imperative that war should be limited to the least degree of necessity. Moreover the peace and freedom are two fundamental requirements of a society. Just as various penal measures help in protecting a society from the evils and excesses committed by an individual, resorting to armed combat sometimes becomes essential to curb the evils perpetrated by countries and nation. ${ }^{24}$ If a nation threatens to disturb the peace and freedom of the world and its arrogance and haughtiness exceed all bounds, a stage may come when the use of armed force and power becomes essential to keep it in check. The holy Qurean asserts that if the use of force had not been allowed in such cases, the disruption and disorder caused by insurgent nations would have reached the extent that the places of worship would have become deserted and forsaken. Therefore Islam allows righteous people to fight against a ferocious and mischief-loving people. Furthermore the holy Quran explain it as follows:-

Permission to fight back is given to those who have been oppressed, and surely Allah is MostPowerfullto bring their victory. Those who were repelled from their homes unjustly only that they said: Our Lord is Allah; had not God permitted people to defend themselves against [the aggression of] others, monasteries, churches, synagogues and mosques, wherein the name of God is oft-mentioned, would be pulled down.( Quran 22: 39 40)

Ibn Abbas was reported to have said that Muslims were driven out of Makkah to Madinah unjustly, i.e. Prophet Muhammad (SAW) and his companions only because they said our Lord is Allah. In other words, they had not done anything to their people or committed any wrongs against them, apart from the fact that they believe in the Oneness of Almighty Allah and they worshipped Him Alone, with no partner or associate. ${ }^{25}$ Thus the Islamic casus belli here, as John Kelsay put it, is a defense of human rights. The above mentioned verses of the holy Qur"ean supports the protection of religious freedom in general since the protection of monasteries, churches, synagogues and mosques is given as a justification for war.Therefore the major objectives of warlike jihad are repelling aggression, preventing persecution against Muslims, and protection of faith in general, fighting those who do not respect treaties on the cessation of hostilities and restoration of peace. Deliverance of weak, the ill-treated, and the persecuted from the forces of tyranny and oppression is among the major

\footnotetext{
22 John Esposito, Unholy War: Terror in the Name of Islam, New York, Oxford University Press, New York, 2002, p. 28.

23 Abdur-Rahman Ibn Khaldun, Muqadimmah Ibn Khaldun ,Makka: al-Maktab al-Tujirahhah, 1994, p. 287.

24 Javid Ahmed Gamdi, Islam: A Comprehensive Introduction, Retrieved from www. javedahmadghamidi.com/meezan/Islam-aComprehensive-Introduction. accessed on January 13, 2015 p. 540.

25 Tifsir Ibn Kather, pp. 584-5
} 
objectives of warfare in Islam. It is an eternal directive of the shariah, as it is undertaken to curb oppression and injustice. Allah says: And why should ye not fight in the cause of God and those who, being weak, are ill-treated (and oppressed)? Men, Women and children, whose cry is: our Lord! Rescue us from the town, whose people are oppressors..."( Qurean, 2:191)Additionally the motive for warfare in Islam is not the difference in religion or an attempt to impose Islamic doctrine. There is no compulsion at all in the dissemination of Islamic doctrine, which is evident from the following verses of the holy Qurean. Let there be no compulsion in religion: truth stands out clear from error. ( Qurean 2:256.) If your Lord had so willed, all those who are on earth would have believed; will you then compel mankind, against their will, to believe?( Qur an 10:99. )

To you be your Way, and to me mine. ( Qur'an109:6.) We showed him the Way: Whether he be grateful or ungrateful (rests on his will)( Qur"ean (76:3)

The above verses of holy Qurean demonstrate that the cause of war in Islam is not elimination and extirpation of infidelity and the subjugation of non-Muslims. But Jihad in the sense of war has specific objectives which can be summarize as repelling transgression; preventing fitna - that is guaranteeing freedom of faith for Muslims and others; saving the oppressed; punishing those who break treaties, and enforcing internal peace within the Ummah. Therefore, objective of jihad does not include imposing Islam on those who do not believe in it, for that contravenes God 's law of diversity and pluralism. In short Islam is a call to peace; it abhors armed combat, but cannot prevent it, hence it prepares for it, but does not wage it unless it is forced upon it, which is due to Islam 'e sealistic nature and its recognition of Sunnat al-tadafu', the law of mutual checking. ${ }^{26}$ However Islam has sought to limit its consequences by surrounding armed combat with rules and ethics.

\section{The Permission for War}

Permission to take up arms is hereby granted to those who are attacked because they have been oppressed and God indeed has power to help them-those who have been unjustly driven from their homes, only because they said: "Our Lord is Allah"eee. ( Qur"ean 22:39-40) This is the first Quranic revelation permitting recourse to armed combat in Islam in which the companions(RTA) of the Prophet(SAW) who had migrated from Makkah to Madina was given permission to fight back in case they were attacked. The Qurean says that these companions of the Prophet (SAW) were driven out of their homes because they believed that Almighty Allah was their Lord and as such they were totally innocent. A little deliberation shows that this one sentence depicts the whole charge-sheet against the Maccan Quraysh.The rationale for this is that no one is willing to leave his home unless he is oppressed for living there and thereby utterly compelled to migrate. The words (because they have been oppressed) refer to very aspect, and it is because of this ruthless and unfounded oppression that the Holy Qur an permitted the Muslims to resort to armed force against aggression. ${ }^{27}$ In others words the war against oppression and injustice is an eternal directive of the Islamic shariah.

\section{Conduct of war in Islam}

Fight in the cause of God those who fight you, but do not transgress limits; for God loveth not transgressors.( Quran 2:190.)“Do not be eager to meet the enemy, but ask God for safety. ${ }^{\text {cee }}$ (A hadith) ${ }^{28}$ The right conduct of Muslim forces has traditionally been an important concern within Islam. Whenever the Prophet of Allah(SAW), sent an army or a group of troops he used to admonish its leader to fear Allah in his personal behaviour and to be pleasant to the Muslims who accompanied him. ${ }^{29}$ The Holy Qurean provides the basis for jus in Bello consideration (content of the law of war): "And fight in God"s cause against those who wage war against you, but do not transgress limits, for God loves not the transgressors". Transgression also means that divine principles and restriction must be respected in all circumstances. The religion of Islam recognizes moral constraints on military conduct, even in war against non-Muslims. The Quranic doctrine on the conduct of armed combat is also shaped by pre-Islamic tribal notion of honour. ${ }^{30}$ The holy Qurean asks believers to honour their promises and agreements: "keep faith with Allah, when you make a convent....Do not break your oaths". ${ }^{31}$ And: "Those who keep faith with Allah do not break their promise". ${ }^{32}$ The religion of Islam also prescribes that the opponent be notified before an attack. Regarding permissible targets of warfare, Quranic

\footnotetext{
${ }^{26}$ Rashid al Ghannoushi, "What is New about Al-Qaradawiees Fiqh of Jihad," Retrieved froim https://Zulkiflihason.files.wordpress.com/2008/06/jihad-in-Islam accessed on January 19, 2015

27 Javid Ahmed Gamdi, Islam: A Comprehensive Introduction. Retrieved from www. Javedahmadghamidi.com/meezan/Islam-a-Comprehensive-Introduction. accessed on January 13 , 2015 p. 540.

28 Muhamad Hamidullah, The Muslim Conduct of state. 6th ed., Sh.Muhammad Ashraf Sons: Lahore, 1973 p. 187.

29 Imam Shaybani, Siyar al Sagir: The short book on Muslim international law translated by Mahmood Ahmad Gazi, Adma Publishers,New Delhi, 2004, p.43.

30 Bassam Tibi, "War and Peace in Islam" Islamic Political Ethics: Civil Society, Pluralism, and conflict / ed by Sohail H. Hashmi, Princeton University Press.

31 Qurean16:19

32 Quran 13:19.
} 
doctrine is in line with the pre-Islamic norm of "man"s boldness" (shahama) in strictly prohibiting the targeting of children, women and elderly. Consistent with this prohibition, as well as the pre-Islamic tribal belief that it is not sign of honor for a man to demonstrate his power to someone who is weaker, is the principle that prisoners be fairly treated. The war in Islam is governed by a moral code, because morals are not an option, but rather an essential part of religion of Islam. Therefore, Islam brought warfare under control and subjected to law as it had not been in pre Islamic Arabia.

\section{CONCLUSION}

In conclusion it can be said that the Jihad as a basic principle of Islam neither excludes the possibility of armed combat nor imposes peace as the sole alternative in all situations. Historically, jihad has been used in several contexts, ranging from self-defence against aggression, injustice, pre-emptive self-defence and conquest. Therefore interpreting Jihad without understanding particular context should not be without serious risk. Thus, it is necessary to pay consideration to the variety of its meanings and applications in any specific situation. The term "jihad" should not be used for a war until this war fulfils the legal conditions for launching it and as long as these conditions are not fulfilled, the launched war should not be called jihad. In addition, major objectives of warlike Jihad are repelling aggression, preventing persecution against Muslims, and protection of faith in general, fighting those who do not respect treaties on the cessation of hostilities and restoration of peace. At last motive for warfare in Islam is not the difference in religion or an attempt to impose Islamic doctrine. But the Islam believes that the value of religion lies in inward persuasion of mind and heart and this cannot be achieved by coercion. Moreover the principle regarding armed combat in Islam is fight in the cause of God those who fight against them, yet Muslims are asked not to transgress limits. In other words the nature of relations between the Muslims and non-Muslim communities is "so long as they remain true to you, be true to them". Finally war is exception because peace is general rule in Islam. 